\title{
Erzurum İli Narman İlçesindeki Sığırcılık İşletmelerinde Uygulanan Sağım Yönetimi Üzerine Bir Araştırma
}

\begin{tabular}{|c|c|}
\hline $\begin{array}{l}\text { Araştırma / Research } \\
\text { Geliş Tarihi / Received } \\
\text { 04.04.2017 }\end{array}$ & $\begin{array}{c}\text { Rıdvan KOÇYİĞIT }{ }^{1}, \text { Mete YANAR }{ }^{1 *}, \text { Recep AYDIN } \\
\text { Abdülkerim DILER } \\
2, \text { Olcay GÜLER }\end{array}$ \\
\hline $\begin{array}{l}\text { Kabul Tarih / Accepted } \\
\text { 23.10.2017 }\end{array}$ & $\begin{array}{c}{ }^{1} \text { Atatürk Üniversitesi, Ziraat Fakültesi, Zootekni Bölümü, Erzurum- Türkiye } \\
{ }^{2} \text { Atatürk Üniversitesi, Erzurum Meslek Yüksekokulu, Bitkisel ve Hayvansal } \\
\text { Üretim Bölümü, Erzurum- Türkive }\end{array}$ \\
\hline $\begin{array}{l}\text { DOI } \\
10.28955 / \text { alinterizbd.303907 }\end{array}$ & $\begin{array}{c}{ }^{3} \text { Atatürk Üniversitesi, Hınıs M.Y.O., Laborant ve Veteriner Să̆lığı Bölümü, } \\
\text { Hınıs, Erzurum-Türkiye }\end{array}$ \\
\hline $\begin{array}{l}\text { ISSN 2564-7814 } \\
\text { e-ISSN 2587-2249 }\end{array}$ & *e-posta:mtyanar@gmail.com \\
\hline
\end{tabular}

Öz: Bu çalışma Erzurum ili Narman ilçesinde, anket yoluyla yüz yüze görüşülerek 208 işletmenin sağım yöntemleri hakkında bilgiler elde etmek amacıyla yapılmıştır. Sağım esnasında işletmelerin $\% 75,5^{\prime}$ inde kesif yem verdiği tespit edilmiştir. Sağım öncesi meme temizliği yapmayan işletmelerin $\% 54,4$ olduğu ve $\% 78,8$ 'inde elle sağım yaptığı belirlenmiștir. Sığır yetiștiricilerinin \%68,6'sı sağımdan sonra sütü alüminyum kaplarda ahır dışında bekletirken, \%30,9'unun ahır ortamında beklettiği ve \%0,5'inin ise soğutma tankında depolamaktadırlar. \%52,2'sinin hayvan başına süt veriminin yaz mevsiminde daha yüksek olduğunu bildirmişlerdir. İşletmelerin \% 78,4'u devletin vermiş olduğu süt desteklemelerinden faydalanmadıkları ve üretilen sütü kayıt altına alan işletmelerin oranının $\% 68,6$ olduğu ve işletmelerin \%24,5'i ineklerini 10 ay sağdıkları tespit edilmiştir.

Sonuç olarak Erzurum ili Narman ilçesindeki sığır yetişicilerinin, sağım öncesi meme temizliği, sağım yapma şekli, sağım sonrası sütleri muhafaza etme, bakanlığın verdiği desteklerden faydalanma, süt verim kayıtlarının tutulması gibi yetiştiricilik konularında bilgilendirilmeye ihtiyaç olduğu belirlenmiştir.

Anahtar Kelimeler: Erzurum, Narman ilçesi, süt sığırı, sağım

\section{A Study on Milking Management Applied in Cattle Enterprises in Narman County of Erzurum Province}

\begin{abstract}
The study was undertaken to obtain information about milking methods of 208 enterprises in Narman County of Erzurum Province via face to face interview. It was determined that concentrate feed was offered during milking in $75.5 \%$ of the enterprises, and Percentage of the enterprises which don't make udder cleaning prior to milking is $54.4 \%$, and hand milking is used in $78.8 \%$ of the enterprises. While $68.6 \%$ of the cattle farmers stores milk in the aluminum milk storage container in the out of barn, $30.9 \%$ of them keeps milk storage containers in the barn and $0.5 \%$ of them stores the milk in the milk cooling tank. $52.2 \%$ of the enterprises indicated that the highest milk yield per animal is obtained in summer season. It was found out that $78.4 \%$ of the enterprises do not utilize from milk support given by the government, percentage of enterprices which keeps milk production records is $68.6 \%$, and $24.5 \%$ of them milks their cows for 10 months.

As a result, it was concluded that cattle farmers in Narman County of Erzurum Province need to be informed about udder cleaning prior to milking, milking methods, storage of milk after milking, utilizing from supports of the goverment, keeping milk records.
\end{abstract}

Keywords: Erzurum, Narman county, dairy cattle, milking

\section{GíRis}

Süt verimi buzağının doğumu ile başlayan ve genel olarak 10 ay boyunca (305 gün) devam eden bir üretim sürecidir. $\mathrm{Bu}$ dönemde sütün uygun bir şekilde sağmal ineğe zarar vermeden sağılması işletmelerin karlılığına ve süt veriminin sonraki süreçlerde artması veya azalmasına etki edebilen önemli bir faktör olarak karşımıza çıkabilmektedir. 
TUiK 2016 y1lı istatistiklerine göre Türkiye'de 14.222.228 büyük baş hayvan mevcut olup, bu sayısal değerin yaklaşık \%38,6'sı (5.495.044 baş) sağmaldır. Sağmal hayvan başına düşen ortalama süt verimi $3066.2 \mathrm{~kg}$ 'dır (TUIK, 2017).

Erzurum büyükbaş hayvan varlığı bakımından 2016 yılı itibarıyla toplam 650.963 baş olup, Türkiye'de sayısal değer bakımından ikinci sırada yer almaktadır.

Erzurum da sağmal hayvan sayısı 252.227 baş olup hayvan başına ortalama süt verimi $2894.9 \mathrm{~kg}$ 'dır. Erzurum'daki sağmal hayvan sayısı Türkiye'deki toplam sağmal hayvanların \% 4,59'ünü oluşturmaktadır (TUIK, 2017).

Narman ilçesi, Erzurum'a 90 km uzakta Doğu Karadeniz ve Doğu Anadolu Bölgelerinin kesişim noktasında, Erzurum ilinin kuzeydoğusunda yer almaktadır. $1275 \mathrm{~km}^{2}$ yüzölçümüne ve $1650 \mathrm{~m}$ rakıma sahip dağlık bir alanda yer almaktadır. İlçe yüksek dağların arasında kaldığından iklimi Erzurum merkeze göre oldukça ılık geçmektedir. Don olayları çok fazla görülmemektedir. Yazları ise sıcak ve kurak geçmektedir. Yağışlar genellikle ilkbahar aylarında olmaktadır. İlçe ekonomisi, hayvancılık ve tarıma dayalı olup aile işletmeciliği şeklindedir. Son yıllarda et tavukçuluğu ve peynir üretim çalışmaları da önemli bir artış olmuştur (Anonim, 2017).

TUIK 2016 yıll verilerine göre Narman ilçesindeki toplam büyükbaş hayvan sayısı 29.480 baş olup bunun \% 73,08'i melez sığırlardan oluşmaktadır. Sağılan hayvanlar içerisinde melez sığırlar 8.722 baş olup, hayvan başına ortalama süt verimi ise 2976.9 kg'dır (TUIK 2017). Konu ile ilgili Erzurum ili merkez ilçe (Çoban et al., 2013) ile Hınıs ilçesinde (Koçyiğit et al., 2016) mevcut sığırcılık işletmelerin yapısal özellikleri ile sağım yönetimi açısından yürütülen araştırmalar mevcut olmasında karşın, ilin kuzey doğusunda yer alan Narman ilçesinde yapılmış bir çalışma mevcut değildir. Bu nedenle, bu araştırma Erzurum ili Narman ilçesinde mevcut sığırcılık işletmelerinin yapısal özelliklerinden sağım yönetimleri ile ilgili mevcut durumu ve sorunları ortaya koymak ve konu ile ilgili çözüm önerileri sunmak amacıyla yürütülmüştür.

\section{MATERYAL VE YÖNTEM}

Araştırmanın materyalini Erzurum ili Narman İlçesi ve köylerinde bulunan 2033 adet sığırcılık işletmesinden tesadüfen seçilmiş 208 işletmeye $(\% 10,23)$ uygulanan anketler oluşturmuştur. Bu tür hesaplamalarda örnek hacminin en az \%3 (Yamane, 2006) veya \%10'unun (Cochran, 1977) alınması yeterli olacağı ifade edilmiştir. Araştırma anketi 2015 yılı Kasım-Aralık aylarında ve işletme sahipleriyle yüz yüze görüşülerek yapılmıştır. Elde edilen veriler Excel 2010 programına aktarılmıştır. SPSS 20.0v (2012) istatistik programında descriptif istatistikte frekans analizi yapilarak sayısal ve oransal değerler elde edilmiştir. Oransal değerler kullanılarak grafikler oluşturulmuş ve sonuçlar yorumlanmıştır.

\section{ARAŞTIRMA BULGULARI VE TARTIŞMA Sağım Esnasında Kesif Yem Verme Uygulaması}

Sağım esnasında kesif yem verme durumu Şekil 1 de verilmiştir. Narman ilçesindeki sı̆̆ı̆ yetiştiricilerinin tamamının günde iki kez sağım yaptıkları ve bu işletmelerin \% 75,5'inde kesif yemin sağmal ineklere sağım esnasında verildiği belirlenmiştir. Bu oran, Soyak (2006)'ın Tekirdağ yöresinde \%69,0 olarak bildirdiği değere yakın olup, Erzurum ili Hınıs ilçesinde (Koçyiğit ve ark., 2016) \%8,0, Kahramanmaraş'ta \%58,0 (Kaygısız ve ark., 2008) ve Tokat yöresinde \%44,4 (Ildız, 1999) olarak bildirilen değerlerden daha yüksek olduğu saptanmıştır. 


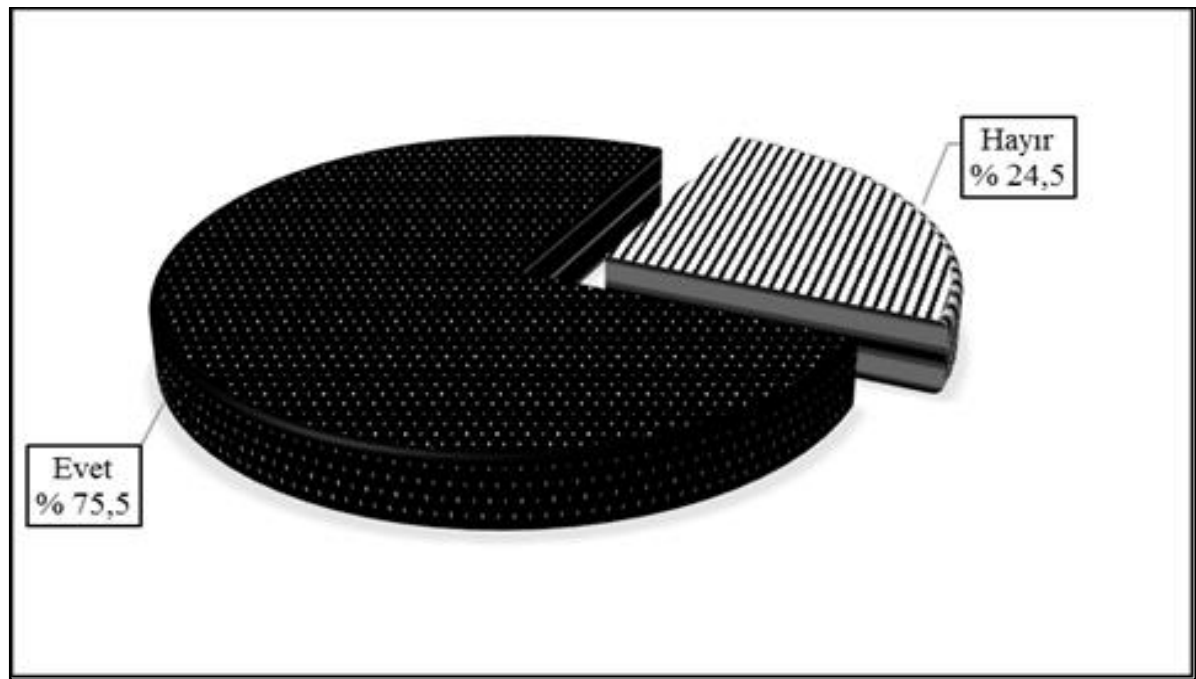

Şekil 1. Sağım esnasında kesif yem verme durumu

\section{Sağım Öncesi Meme Temizliği}

Sağım öncesi meme temizliği yapma durumu Şekil 2'de görüleceği üzere işletmelerin $\% 54,4$ 'ün de sağım öncesi meme temizliği yapıldığı, \%45,6'inde ise yapılmadığı tespit edilmiştir. Erzurum ili Hınıs ilçesinde yapılan bir çalışmada (Koçyiğit ve ark., 2016), işletmelerin \% 85,0'inde sağım öncesi meme temizliği yapıldığı bildirilmiştir. Ülkemizde yapılan diğer araştırmalarda ise, sağım öncesi meme temizliği yapan işletmelerin oranı, Ildız (1999)'ın Tokat yöresi için \%66,6; Soyak (2006) Tekirdağ ilinde \%96.0; Tatar (2007) Ankara ve Aksaray'da sirasiyla \%98,4 ve \%96,5, Kaygısız ve ark., (2008) Kahramanmaraş'ta \%78,0, Özyürek ve ark., (2014) Erzincan ili Çayırlı ilçesinde \%93,3 ve Demir ve ark., (2014) Kars ilinde \%52,5 olarak bildirilmiştir. Bogdanovic ve ark., (2012) ise, Surbistan'da yapılmış olan bir araştırmada sağım öncesi meme temizliğine işletmecilerin çok önem verdiklerini ve rutin olarak yaptıklarını ifade etmişlerdir. Narman ilçesindeki sığırcılık işletmelerinin sağım öncesi meme temizliği uygulama oranındaki düşüklüğün, Kars ili hariç yurdumuzun diğer yörelerine göre çok düşük seviyede kaldığı, bu uygulamanın en kısa sürede yükseltilmesi konusunda yetiştiricilerin alışkanlıklarını değiştirmesi ve bu amaçla eğitim çalışmalarında sağım öncesi meme temizliği ve hijyeni konusuna daha fazla önem verilmesi gerekliliği sonucu ortaya çıkmaktadır.

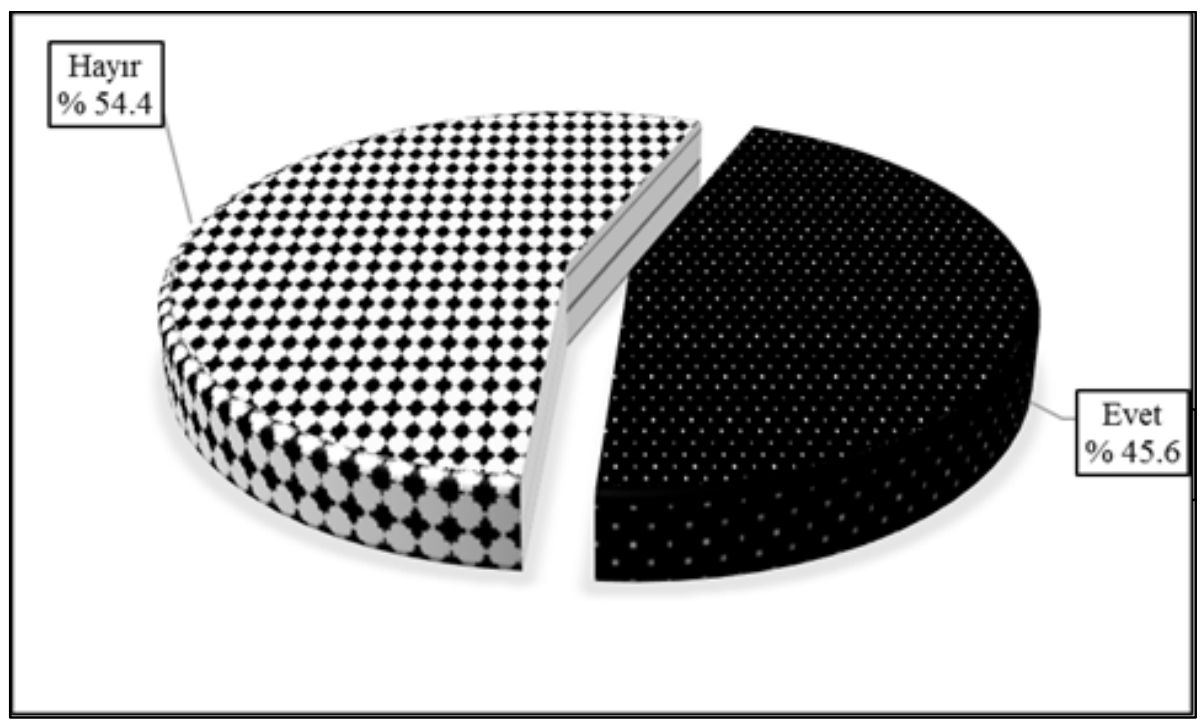

Şekil 2. Sağım öncesi meme temizliği yapma durumu 


\section{Uygulanan Sağım Metodu}

Şekil 3'te uygulanan sağım metodu incelendiğinde Erzurum ili Narman ilçesinde sı̆̆ır yetiştiricilerinin, \%78,8 'inin elle , \%20,7'sinin seyyar makine ile çok düşük oranda ise ayrı sağım ünitelerinde $(\% 0,5)$ sağım yaptıkları tespit edilmiştir (Şekil 3).

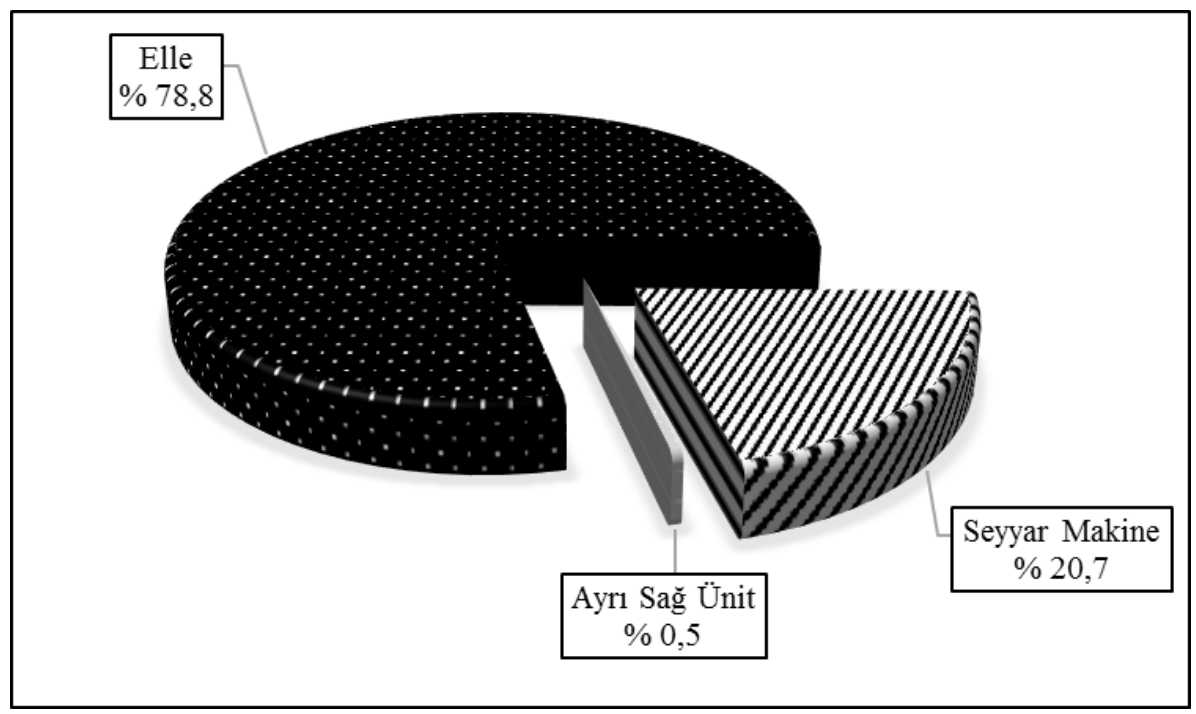

Şekil 3. Sağım metodu

Benzer şekilde yurdumuzun doğu bölgelerinde yürütülen araştırmalarda da, yaygın olarak elle sağımın uygulandığı rapor edilmektedir. Örneğin, Erzurum ili Hınıs ilçesinde işletmelerin \%89,0'unda (Koçyiğit ve ark., 2016), Van'da \%96,5'inde (Bakır, 2002), Erzincan ili Çayırlı ilçesinde \%81,0 (Özyürek ve ark., 2014) ve Kars ilinde \%78,4 oranlarında (Demir ve ark., 2014) sağımın elle yapıldığı bildirilmiştir. Bulgularımızdan farklı olarak yurdumuzun özellikle orta ve batı yörelerinde, makine ile sağımın daha yaygın olduğunu bildiren çalışmalarda mevcut olup, Tekirdağ ilinde makine ile sağım oranını Akman ve Özder, (1992) ile Soyak ve ark., (2007) sirasıly \%76,0 ve \%93,0; Tatar (2007) Ankara'da \%95,2; Aksaray'da \%94,4 ve Önal ve Özder (2008) ise Edirne ilinde tüm işletmelerin sağımı makine ile yaptıklarını bildirmişlerdir. Sırbistan'da süt sığırcılı̆̆ı yapan işletmelerin yaygın olarak ve özellikle büyük işletmelerde balık kılçığı şeklinde otomatik sağım sistemi, küçük işletmelerde özel süt toplama makinaları ile sağım ve vakumlu boru hattı sağım sistemi olmak üzere 3 farklı sağım sistemi kullandıkları ifade edilmiştir (Bogdanovic ve ark., 2012).

\section{Sağım Sonrası Sütün Muhafaza Edildiği Ortamlar}

İşletmelerde sağım sonrası sütün muhafaza edildiği ortamlar Çizelge 4'te sunulmuştur. İşletmelerin \%68,6'sının sütü sağım sonrasında ahır dışında alüminyum kaplarda beklettiği, \%30,9'unun ahır ortamında beklettiği ve \%0,5'inin ise soğutma tankında depoladıkları belirlenmiştir (Şekil 4). Benzer şekilde Koçyiğit ve ark. (2016) Hınıs ilçesinde işletmelerin büyük bir kısmının (\%73,0) sütü alüminyum kovalarda depoladıklarını bildirmişlerdir. 


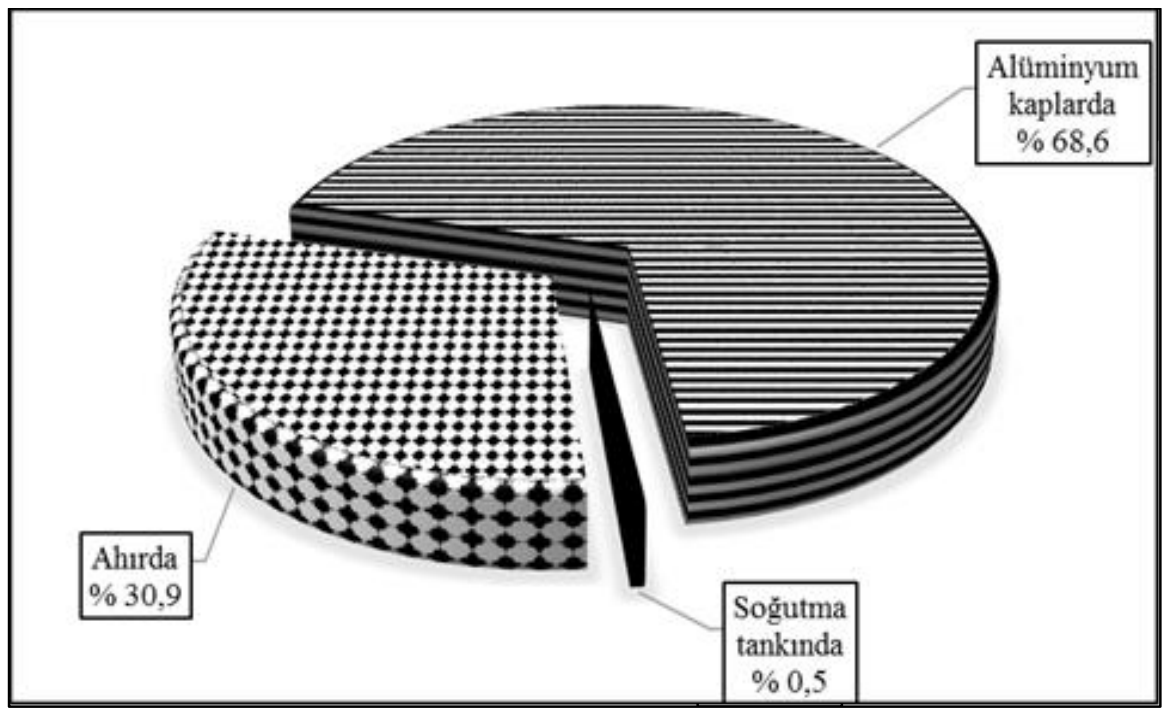

Şekil 4. Sağım sonrası sütün muhafaza edildiği ortamlar

$\mathrm{Bu}$ çalışmada ankete katılan işletmelerin çok azının $\left(\% 0,5^{\prime} \mathrm{i}\right)$ sütü uygun koşullarda (soğutma tankında), büyük bir kısmının ise uygun olmayan şartlarda depoladığı belirlenmiştir. Uygun olmayan şartlarda depolanan sütün kalitesi kısa sürede düşmekte ve önemli ekonomik kayıplara yol açmaktadır. Sütün ekonomik değere sahip bir ürün olduğu göz önüne alındığında, soğuk zincir kurularak bu ürünün sağlıklı ve hijyenik olarak mandıra ya da süt fabrikalarına ulaştırılması için gerekli olan hassasiyetler gösterilmeli ve gereken önlemler alınmalıdır.

\section{Buzağılama Ve Süt Verim Mevsimi}

Şekil 5 'te buzağılama mevsimi tercihi incelendiğinde ankete katılan işletmelerin \%52.4'ünde buzağı doğum mevsimi açısından herhangi bir tercihin olmadığı, buzağılamaların herhangi bir mevsimde olabileceği sonucu çıkmaktadır.

Doğumun ağırlıklı olarak İlkbahar ve Sonbaharda gerçekleştiğini belirten işletmelerin oranları ise sırasıyla \%19,2 ve \%18,8 olarak saptanmıştır (Şekil 5). Erzurum ilinde Çoban ve ark., (2013) tarafından yapılan bir çalışmada da, yetiştiricilerin \%83,9'unun buzağılama mevsiminin kış ve ilkbahar aylarında olmasını istediklerini rapor edilmiştir. Erzurum ili Hınıs ilçesinde yapılan bir araştırmada, işletmelerin \%68,0'i doğumların sonbaharda olmasını arzu ederken, \%6,0'sı doğumların kış mevsiminde olmasını istediklerini belirtmişlerdir. Bu tür süt sığırcıllığı yapan işletmelerde ekonomik öneme sahip olan sütün yll boyunca sürekli üretilmesi ve işletmeye sürekli bir gelir olarak geri dönmesi işletmelerin ekonomikliği açısından önem arz eden bir durumdur. Bu nedenle doğumların yıl içerisinde dağıtılması veya en az yılda 2 kez doğumların yoğun olarak gerçekleşmesi sığı̆rcılık işletmeleri açısından önemlidir. 


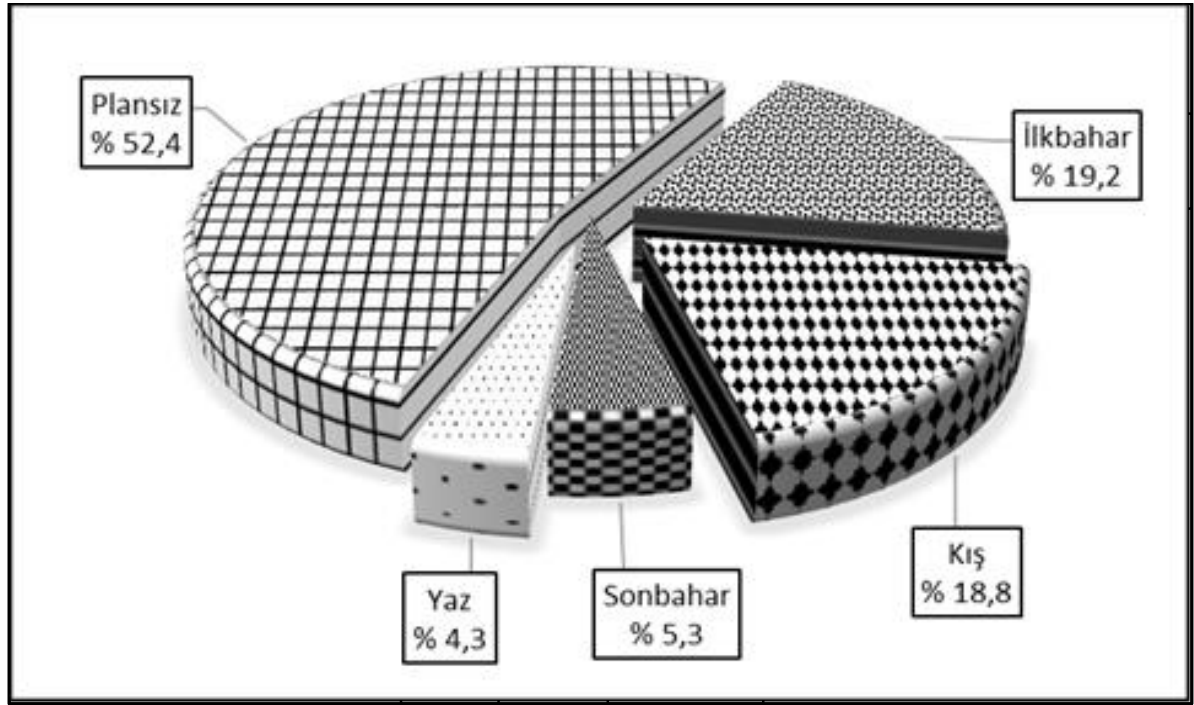

Şekil 5. Buzağılama mevsimi

Şekil 6'da hayvan başına süt veriminin daha fazla olduğu mevsim gösterilmiştir. İnek başına süt veriminin en fazla yaz $(\% 52,2)$ ve ilkbahar $(\% 47,3)$ aylarında olduğu tespit edilmiştir (6). Bunun nedenleri arasında, söz konusu dönemlerin laktasyonun en üst düzeye çıktığı devrelere

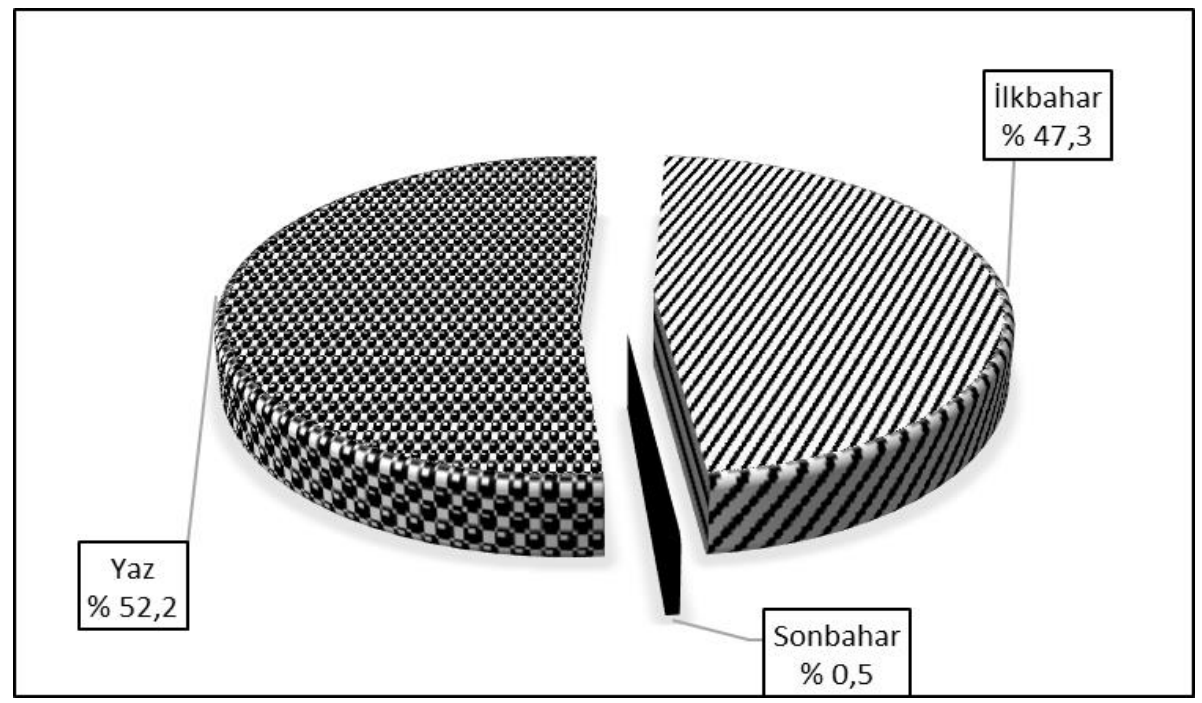

Şekil 6. Hayvan başına süt veriminin daha fazla olduğu mevsim

rastlaması ve meraya otlatılmaya çıkarılan hayvanların taze ve sulu yeşil yem tüketiminin artması ve iklim koşullarının bir sonucu olarak yaz döneminde sıcaklık değerlerinin sığırlarda sıcaklık stresi oluşturacak düzeylere çıkmaması sayılabilir. Benzer bir şekilde, Erzurum ili Hınıs ilçesinde de süt sığırlarında süt veriminin yaz aylarında $(\% 61,0)$ maksimum seviyeye ulaştığını Koçyiğit ve ark. (2016) tarafindan da bildirilmiştir.

\section{Tarım Bakanlığının Süt Desteklemesinden Faydalanma}

Tarım Bakanlığının süt desteklemesinden faydalanma durumu Şekil 7’de sunulmuştur. 


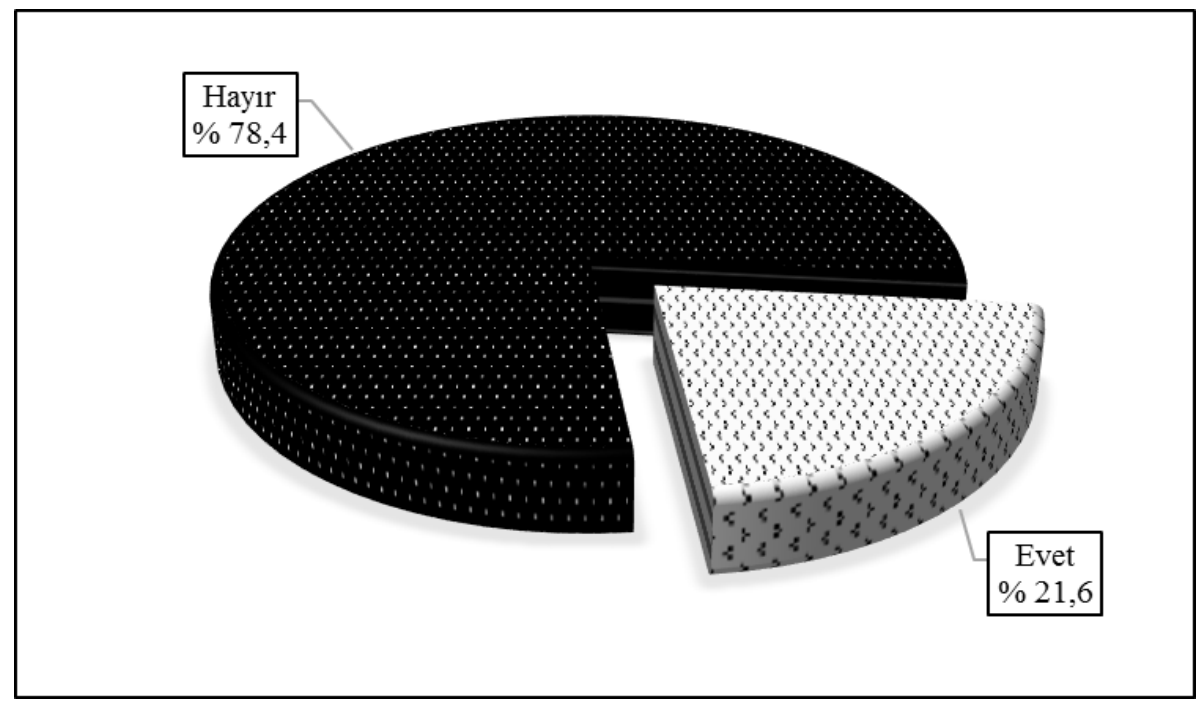

Şekil 7. Tarım Bakanlığının süt desteklemesinden faydalanma

Narman ilçesindeki yetiştiricilerin \%21,6'sının devletin süt destekleme programlarından yararlandığı tespit edilmiștir. Özellikle son dönemlerde verilen desteklemelerde işletmelerin istenen koşulları sağlayamaması, bir kooperatif veya birliğe üye olmaması gibi nedenlerle bakanlığın vermiş olduğu süt teşviklerinden faydalanan işletme sayısının az olmasına sebep olduğu düşünülmektedir. Erzurum ili Hınıs ilçesinde bu oranın \%9.0 düzeylerinde olduğu araştırıcılar tarafından ifade edilmiştir (Koçyiğit ve ark., 2016).

\section{Üretilen Sütün Satıldığı Yerler Ve Süt Verim Kayıtlarını Tutma Durumu}

İşletmelerde üretilen sütün satıldığı yerler Şekil 8'de süt verim kayıtlarını tutma durumu ise Şekil 9'da sunulmuştur. Süt sığırcilığında istenilen özellik ve kalitede süt üretilmesi ile sütün satılması ve satış fiyatının her zaman için yüksek olması işletmelerin karlılığını ve devamlılığını büyük ölçüde etkilemektedir Araştırmada elde edilen sonuçlara göre işletmelerin \%65,4'ü ürettikleri sütü aracılara yada süt toplayıcılarına verdikleri, \%19,7'sinin ise kendi ihtiyaçları doğrultusunda kullandıkları, $\% 13,9$ 'ünün fabrikalara veya mandıralara ve \%1,0' inin ise birliklere verdiği belirlenmiştir (Şekil 8). Kooperatifler veya birlikler gibi organizasyonlar kurularak sütün müşterek bir tankta toplanılması ve bu organizasyonlar vasıtasıyla sütün pazarlanması sütün kalitesini artırmakla beraber daha yüksek fiyatla istenildiği şekilde pazarlanmasına olanak sağlayabilir.

Çalışmada elde edilen sonuçlar bazı literatür sonuçlarından farklılık arz etmektedir. Bakan ve Aydın (2016) Ağrı ilinde yaptıkları bir araştırmada, işletmecilerin $\% 15,1$ ' $\mathrm{i}$ süt toplayıcılarına, $\% 2,8^{\prime} \mathrm{i}$ mandıraya, \%82,1'i diğer şekillerde (ev ihtiyacı, isteyene satış vs) değerlendirmekte olduğunu bildirmişlerdir. Demir ve ark., (2014) Kars ilinde 162 işletmede yaptıkları bir çalışmada sütün pazarlanma yeri olarak işletmelerin $\% 56,8^{\prime} \mathrm{i}$ mandıralara, $\% 21,0$ 'si ürettiği sütü kendinin pazarladığını, \%14,2'sinin ise fabrikalara verdiğini ifade etmişlerdir. Şahin (2001) Kayseri ilinde süt sığırcılığı faaliyetinde bulunan işletmelerin bir kısmı sütünü ilçe halkına sattığını ve sokak sütçüleri aracılığı ile toplanan sütlerin ise Kayseri şehir merkezine götürülmek suretiyle satıldığını bildirmiştir. 


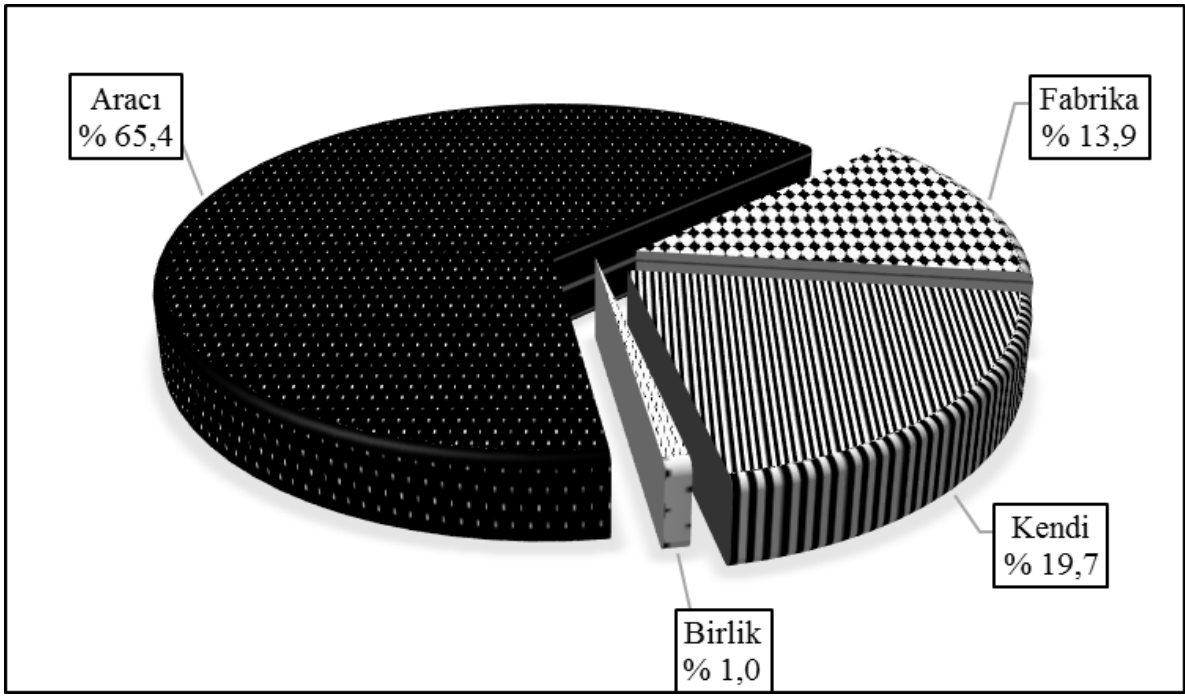

Şekil 8. Üretilen sütün satıldığı yerler

Ankete katılan işletmelerin \%31,4'i üretilen sütlerin kayıt altına aldıklarını ifade ederken \%68,6'sinin ise hiçbir şekilde kayıt tutmadıkları belirlenmiştir (Şekil 9). Karlı bir hayvancılık ve hayvanların genel anlamda verim düzeylerinin ölçütlerini ortaya koymak için süt verim kayıtlarının mutlaka kayıt altına alınması gereklidir. Bu yolla sürüde tutulacak veya atıl olacak hayvanların belirlenmesi daha kolay olacak ve süt verimi yüksek olan sığırlar ile düşük olan sığırlar arasındaki farklı yemleme programların oluşturulmasında da yetiştiriciye yol gösterebilecektir.

$\mathrm{Bu}$ çalışmadan elde edilen sonuçlardan farklı olarak, süt verim kayıtlarını tutan işletme sayısını Özyürek ve ark., (2014) Erzincan ili Çayırlı ilçesinde \%47,7, Nizam (2006) Aydın ili için \%40,0 olduğunu bildirmişlerdir. Narman ilçesindeki işletmelerin bu konuda bilgilendirilmesi ve kayıt tutmanın öneminin anlatılması gerektiği düşünülmektedir.

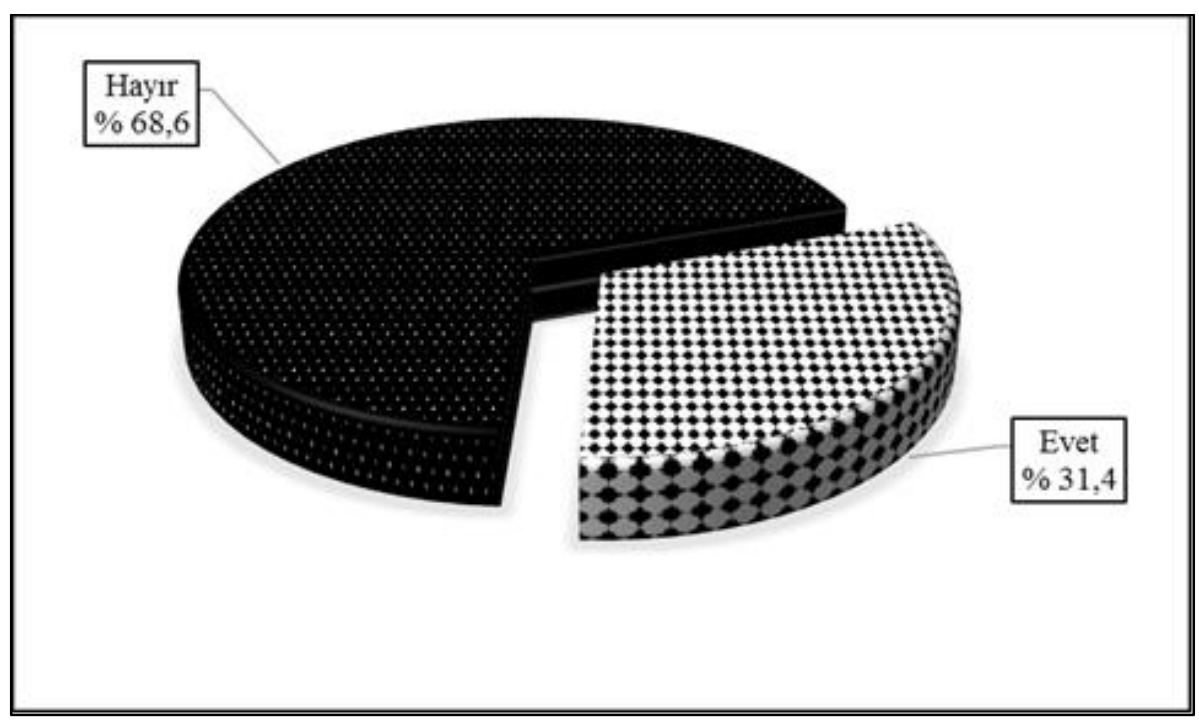

Şekil 9. Süt verim kayıtlarının tutulması

\section{İneklerin Laktasyon Süresi}

İneklerin ortalama laktasyon süresi (ay) Şekil 10'da verilmiştir. Erzurum ili Narman ilçesindeki yetiştiricilerin \%24,5'i inekleri 10 ay sağdıkları belirlenmiştir (Şekil 10). İdeal bir sığır yetiştiriciliğinde normal olarak bir inek 10 ay boyunca sağılır ve doğuma 2 ay kala kuruya çıkartılır. Çalışmanın yapıldığı yörede işletmelerin $\% 75,5$ 'i 10 aydan daha az sürede hayvanlarını sağdıkları belirlenmiştir. Yapılan bir diğer anket çalışmasında Kars ilinde işletmelerdeki ineklerin ortalama 
laktasyon süresi 6 ay olarak tespit edilmiştir (Demir ve Aral 2009). Laktasyon süresinin ideal sürenin altında olması muhtemelen mevcut sığır varlığının \%79'nu oluşturan melez ve yerli sığırların genetik yapılarının düşüklüğü, yüksek verimli erkek genotiplerle döllenerek yeni generasyonlarda verimi yükseltme ihtiyacının söz konusu olmaması ve yetersiz bakım ve besleme uygulamaları gibi nedenlere bağlanabilir.

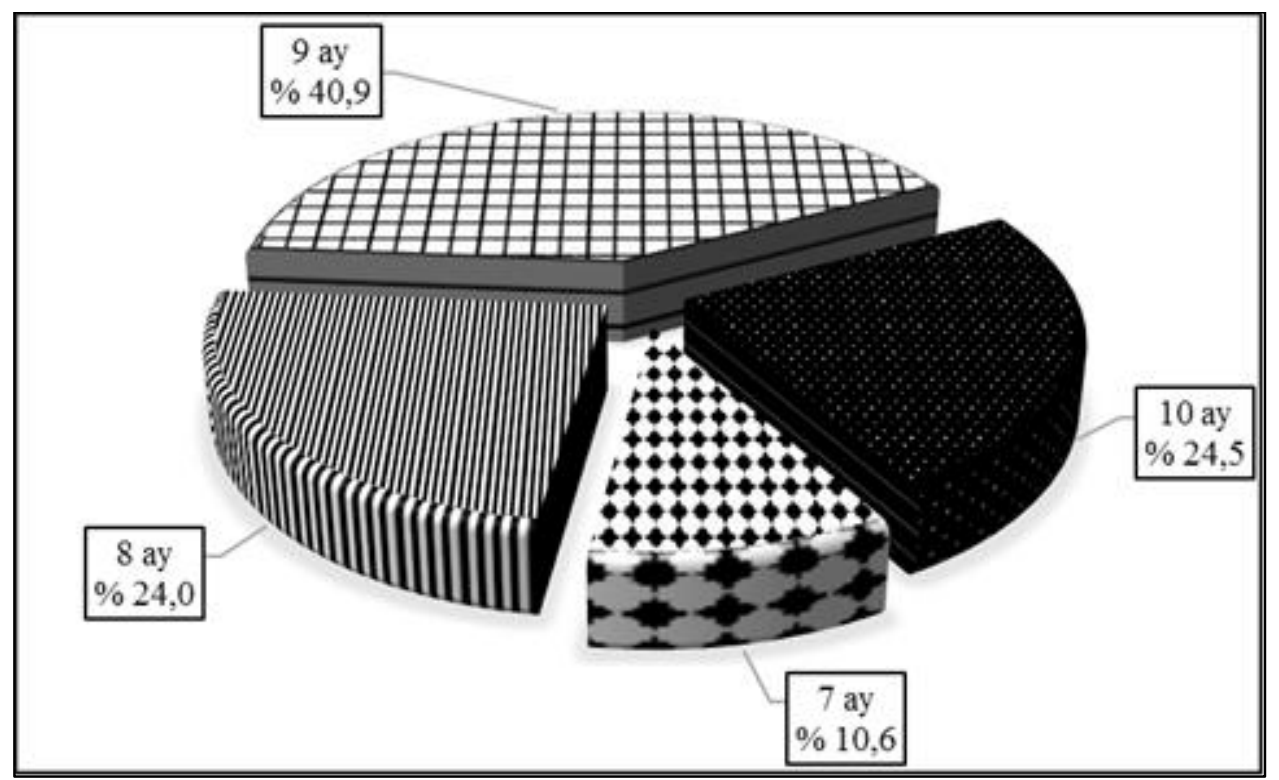

Şekil 10. İneklerin ortalama laktasyon süresi (ay)

\section{SONUÇ VE ÖNERILER}

Erzurum ili Narman ilçesindeki işletmelerde sağım öncesi meme temizliği yapılmaması, sağım sonrası sütü depolama koşullarının uygun olmaması nedeniyle temiz ve kaliteli süt elde edilememesine, elle sağım yapan işletmelerin oranının yüksek olması daha fazla zaman ve enerji kaybına neden olmaktadır. Ayrıca İneklerin ortalama laktasyon süresinin düşük olması daha düşük süt elde edilmesine ve işletmelerin gelirlerinin düşmesine neden olabilmektedir. Bakanlığın verdiği teşviklerden yeterince faydalanılmaması ve işletmelerin süt verim kayıtlarını tutmamasıda yine işletmelerin hem gelirlerinin düşmesine hemde kar ve zararlarının belirsizliğine neden olmaktadır.

Sonuç olarak, işletmelerde temiz ve kaliteli süt elde etmek için makine ile sağım imkanı sunmak, sütün muhafazası ve soğuk zincir akışının sağlanması konusunda Narman ilçesinde süt sığırcılığı yapan üreticilerin bilinçlendirilmesi ile daha nitelikli bir hayvancılık yapılması sağlanabilir.

\section{KAYNAKLAR}

Akman, N., Özder, M., 1992, Tekirdağ ilinde ithal ineklerle çalışan işletmelerin durumu ve sorunları' Trakya Bölgesi 1. Hayvancilık Sempozyumu. Tekirdağ, 1992.

Anonim, 2017. https://tr.wikipedia.org/wiki/Narman. Erişim tarihi: 05.01.2017.

Bakan, Ö., Aydın, R., 2016. Ağrı İli Süt Sığırcılığı İşletmelerinin Sosyo-Ekonomik Özellikleri. Journal of the Faculty of Agriculture,,47(2): 113-122.

Bakır, G., 2002. Van İlindeki Özel Süt Sı ̆̆ırcılığı İşletmelerinin Yapısal Durumu. Yüzüncü Yıl Üniversitesi, Ziraat Fakültesi., 12 (2): 1-10.

Bogdanovic, V., Dedovic, R., Perisic, P., Stanojevic, D., Petrovic, M.D., Trivunovic, S., Kucevic, D., Petrovic, M.M., 2012. An assesment of dairy farm structure and characteristics of dairy production sytems in Serbia. Biotechnology in Animal Husbandry,, 28 (4): 689-696.

Cochran, W.G., 1977. Sampling Techniques. 3rd Edition. John Wiley\&Sons. New York.

Çoban, O., Lacın, E., Sabuncuoglu, N., Genc, M., 2013. Production and health parameters in cattle herds: A survey from Eastern Turkey. The Journal of Animal and Plant Sciences., 23(6):1572-1577.

Demir, P., Adıgüzel , S.I., Sarı, M., Ayvazoğlu, C., 2014. Kars merkez ilçedeki süt sığırcılık işletmelerinin genel yapısı ve ekonomik boyutu. Fırat Üniversitesi Sağlık Bilimleri Veteriner Dergisi., 28(1): 9-13.

Demir, P., Aral, S., 2009. Kars ilinde faaliyet gösteren süt sığırcılık işletmelerinin karşılaştıkları sorunlar ve çözüm önerileri. Vet. Hek. Der. Derg., 80 (3): 17-22.

Demir, P., Yılmaz, A. R. A. L., Sarı̈zkan, S., 2014. Kars İli Süt Sığırcılık İşletmelerinin Sosyo-Ekonomik Yapısı ve Üretim Maliyetleri. Yüzüncü Y1l Üniversitesi Veteriner Fakültesi Dergisi.,25(1): 1-6. 
Ildız, F. 1999. Tokat ili merkez ilçesinde ithal sığır yetiştiren tarım işletmelerinin yapısı. Ankara Üniversitesi Fen Bilimleri Enstitüsü, Zootekni Anabilim Dalı. (Yüksek Lisans Tezi, Basılmamış). Ankara.

Kaygısız, A., Tümer, R., Orhan, H., Vanlı, Y., 2008. Kahramanmaraş bölgesi süt sığırı işletmelerinin yapısal özellikleri: I. Yetiştirme uygulamaları. Süleyman Demirel Üniversitesi Ziraat Fakültesi Dergisi., 3(2): 23-31.

Koçyiğit, R., Aydın, R., Diler, A., Güler, O., Yanar, M., 2016. Erzurum İli Hınıs İlçesindeki Sığırcılık İşletmelerinin Yapısal Özellikleri: Sağım Yönetimi. Harran Tarım Ve Gıda Bilimleri Dergisi., 20(4): 322-329.

Nizam, S., 2006 . Aydın ilinde pazara yönelik süt sığırcılığı işletmelerinin verimliliklerinin belirlenmesi. Adnan Menderes Üniv. Fen Bil. Enst. Yük. Lis. Tezi.

Önal, A.R., Özder, M., 2008. Edirne ili damızlık sığır yetiştiricileri birliğine üye işletmelerin yapısal özellikleri. Tekirdağ Ziraat Fakültesi Dergisi., 5 (2):197-203.

Özyürek, S., Kocyigit, R., Tüzemen, N., 2014. Erzincan ilinde süt sığırcıllı̆̆ yapan işletmelerin yapısal özellikleri: Çayırlı İlçesi örneği. Tekirdağ Ziraat Fakültesi Dergisi., 11(2):19-26

Soyak, A., 2006. Tekirdağ ili süt sığırcıllı̆ı işletmelerinin yapısal özellikleri ve bu işletmelerin Siyah Alaca süt sığırı popülasyonunun çeşitli morfolojik özellikleri üzerine bir araştırma. Yüksek Lisans Tezi, Trakya Üniversitesi, Fen Bilimleri Enstitüsü, Tekirdağ.

Soyak, A., Soysal, M.İ., Gürcan, E.K., 2007. Tekirdağ ili süt sığırcılığı işletmelerinin yapısal özellikleri ve bu işletmelerdeki Siyah Alaca süt sığırlarının çeşitli morfolojik özellikleri üzerine bir araştırma. Tekirdağ Ziraat Fakültesi Dergisi., 4 (3):297-305.

SPSS 2012. Analysis Without Anguish: Version 20 for Windows. John Wiley and Sons Australia

Şahin, K., 2001. Kayseri ilinde süt sığırcılığı yapan işletmelerin yapısal özellikleri ve pazarlama sorunları. Yüzüncü Yıl Üniversitesi Tarım Bilimleri Dergisi,11(1): 79-86.

Tatar, A., M., 2007 Ankara ve Aksaray Damızlık Sığır Yetiştiricileri İl Birliklerine Üye Süt Sığırı İşletmelerinin Yapısı ve Sorunları. Doktora Tezi, Ankara Üniversitesi, Fen Bilimleri Enstitüsü, Ankara.

TÜIK, 2017. Türkiye İstatistik Kurumu, Hayvancillk İstatistikleri. https://biruni.tuik.gov.tr/hayvancilikapp/hayvancilik.zul Erişim tarihi: 05.01.2017.

Yamane, T., 2006. Temel Örnekleme Yöntemleri. Çev. Esin A, Bakır MA, Aydın C, Güzbüzsel E. Literatür Yayınlar1: 53, İstanbul. 